\title{
What dermatologists should communicate
}

\author{
Dr. Carolina Diamandis ${ }^{1}$, Dimitri V Bodrov ${ }^{1}$, and Alexander Davis ${ }^{1}$
}

${ }^{1}$ Affiliation not available

May 13, 2021

\begin{abstract}
In the case of a suspicious skin mole, the question always arises as to whether it is benign or malignant. Is it a harmless mole, a capillary malformation or a basal cell carcinoma, squamous cell carcinoma or even a melanoma? Often the nevus can already be assessed by a close examination of the lesion and a few questions regarding its development. But most important: the patients need to be informed about their condition in a simple but professional way.
\end{abstract}

\section{Hosted file}

What dermatologists should communicate.pdf available at https://authorea.com/users/410930/ articles/521926-what-dermatologists-should-communicate 